\title{
Phytochemical Profiling and in vitro Antioxidant Activity of Leafless Mistletoe Viscum articulatum Burm.f. by DPPH Assay
}

\author{
Manoj R. Kakpure*
}

Assistant Professor, Department of Botany, L.R. Bharti Arts, Commerce \& S. S. R. Bharti Science College, Arni, Dist-

Yavatmal, Maharashtra, India

*Address for Correspondence: Dr. Manoj R. Kakpure, Assistant Professor \& Head, Department of Botany, L.R. Bharti Arts, Commerce \& S. S. R. Bharti Science College, Arni, Dist-Yavatmal, Maharashtra, India

E-mail: manojkakpure@rediffmail.com

Received: 18 May 2020/ Revised: 23 Aug 2020/ Accepted: 29 0ct 2020

\begin{abstract}
Background: Viscum articulatum Burm.f. is a hemiparasitic plant belongs to family Viscaceae, which having various traditional medicinal uses. The present work was attempted to determine phytoconstituents and in vitro antioxidant activity of $V$. articulatum by using DPPH scavenging assay to evaluate their potential as to elucidate pharmacological actions.

Methods: The dried plant material powdered administered to soxhlet extraction with petroleum ether, benzene, chloroform, acetone, ethanol and distilled water respectively for $18 \mathrm{~h}$. The condensed extracts were tested for qualitative assessment of phytochemicals. In vitro, antioxidant activity was conducted via DPPH radical scavenging assay. Antioxidant activity was assessed with acetone and ethanolic crude extract to evaluate the free radical scavenging activity (Inhibition (\%)/ Scavenging) of $V$. articulatum at different concentrations of stock solution likes $50,100,150,200$, and $250 \mu \mathrm{g} / \mathrm{ml}$.

Results: Phytochemical investigation prominently reveal the presence of phytoconstituents like carbohydrates, cardiac glycosides, proteins, alkaloids, fats, saponin, coumarins, flavonoids, tannins, phenolics, steroids and quinone, which have been responsible for various biological activities. The $\mathrm{IC}_{50}$ value of acetone and ethanol extract of the studied plant was found to be 9.4 and 8.9 respectively, which was comparable with standard ascorbic acid $\left(I C_{50}=5.4\right)$.

Conclusion: The results suggest that $V$. articulatum exhibits the excellent potential of antioxidant activity that may be beneficial for its medicinal values.
\end{abstract}

Key-words: Antioxidant activity, DPPH assay, in vitro, Phytochemical, V. articulatum

\section{INTRODUCTION}

Since ancient times, plants are a vital source of bioactive compounds with antioxidant properties [1]. An antioxidant is known as the substance that inhibits a target molecule's oxidative damage ${ }^{[2,3]}$. The essential substances that can protect the body from damage caused by free radical oxidative stress are antioxidants [4]. An antioxidant's key particularity is its ability to trap free radicals. Many ailments, including cancer, Parkinson's disease, Alzheimer's disease, cardiovascular disorders and neurological disorders, can be caused ${ }^{[5]}$.

\section{How to cite this article}

Kakpure MR. Phytochemical Profiling and in vitro Antioxidant Activity of Leafless Mistletoe Viscum articulatum Burm.f. by DPPH Assay. SSR Inst. Int. J. Life Sci., 2020; 6(6): 2709-2716.

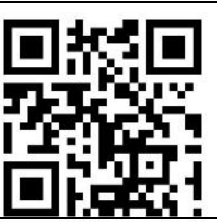

Often responsible for human ageing are reactive oxygen species ${ }^{[6]}$. The oxidative processes that lead to degenerative diseases are blocked by antioxidant substances such as phenolic acids, polyphenols and flavonoids that scavenge free radicals ${ }^{[7,8]}$. They are occurring naturally and through synthetic chemical processes. There is now a growing trend to substitute synthetic antioxidants with natural antioxidants because safety is a concern ${ }^{[9]}$. The epidemiological studies have revealed that the utilization of natural antioxidants is related to a lower risk of cardiovascular diseases and cancer. The natural antioxidants are isolated products of plant origin ${ }^{[10]}$. So, herbal plants considered as an excellent antioxidant since long years ago.

$V$. articulatum Burm.f. is a hemiparasitic plant belongs to family Viscaceae commonly parasite on the stem of Diospyrous melanoxylon Roxb. and Boswellia serrata Roxb. Also, it is rarely epiparasites on the stem of 
Dendropthae falcata (L.f.) Ett. This plant is used traditionally for anti-cancerous properties, bone fractures, febrifuge, inflammations, lumber muscles strain, psoriasis, rheumatic swelling and urinary tract infection.

Therefore, the present work was attempted to evaluate phytoconstituents and in vitro antioxidant activity of $V$. articulatum plant by using DPPH scavenging assay to assess their ability to elucidate pharmacological activities.

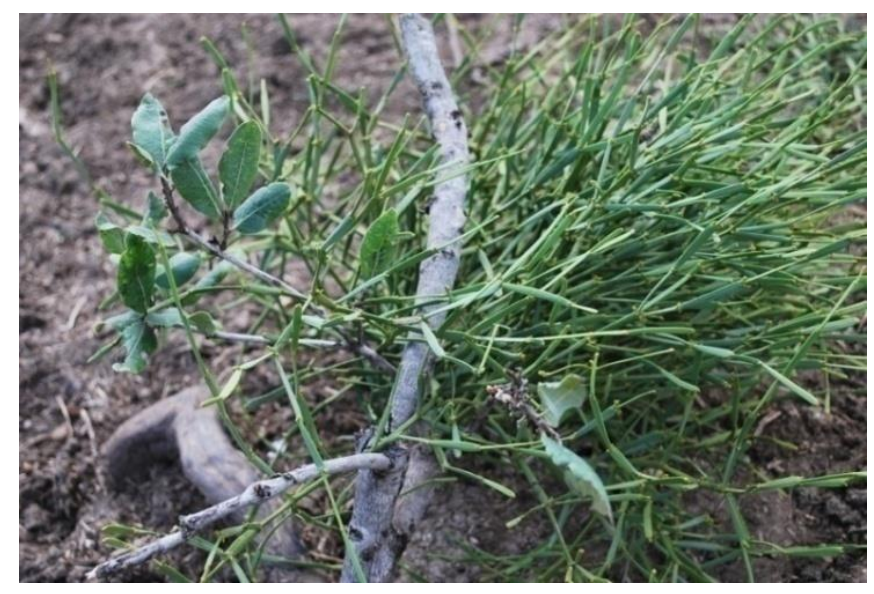

Fig. 1: Plant of $V$. articulatum Burm.f.

\section{MATERIALS AND METHODS}

The plant materials under study, i.e. V. articulatum Burm. f. was collected during the period of flowering and fruiting from Melghat forest region district Amravati. The herbarium specimen was prepared, identified with the help of standard floras ${ }^{[11-13]}$ and the study was carried out in December 2018 at the Department of Botany, Bharti Mahavidyalaya Arni, district Yavatmal, Maharashtra, India.

Phytochemical analysis- The collecting plant material was washed and shade dried. The dried plant material is powdered by using grinder mixer and in the order of increasing polarity of solvents, it was subjected to soxhlet extractions with petroleum ether, benzene, chloroform, acetone, ethanol and distilled water for 18 hrs, respectively. The condensed extracts were used for qualitative assessment of phytochemicals. It involved the examination of various classes of compounds. A qualitative chemical test followed by the method chosen for the identification of different phytoconstituents to provide a general idea about the existence of constituents present in crude drugs ${ }^{[14-17]}$. The extracts were analyzed for the presence of phytochemicals like carbohydrates, cardiac glycosides, alkaloids, flavonoids, tannin, phenolics, steroids, coumarins and saponin.

In Vitro Antioxidant activity- The DPPH radical scavenging assay carried out the antioxidant activity of $V$. articulatum ${ }^{[18]}$ in acetone as well as ethanol extract. The percentage \% of scavenging (inhibition) is calculated in triplicates.

Preparation of acetone and ethanolic extract- Total 100 gm dried plant powder extracted with acetone and ethanol in increasing order of nature of polarity of solvent by Soxhlet apparatus. By using a rotary flash evaporator, the extracts were concentrated then dried in a desiccator with the residue.

\section{DPPH Radical Scavenging Assay (2,2-diphenyl-1-}

Picrylhydrazyl)- Based on the radical scavenging effect of the stable DPPH radical, the anti-oxidant activity of $V$. articulatum acetone and ethanolic extracts were carried out. DPPH is a stable free radical, which can accept hydrogen radical electrons to become a stable diamagnetic molecule. DPPH shows a potent absorption band at $517 \mathrm{~nm}$. Antioxidant reacts with DPPH, which is a stable free radical and reduces DPPH to DPPH-H $(2,2-$ diphenyl-1-Picrylhydrazine). The absorption decreases in the degree of discolouration from the DPPH radical (Purple) to DPPH-H (Yellow) indicates the scavenging potential of the antioxidant compound or extracts in terms of the ability to donate hydrogen ${ }^{[19-22]}$.

\section{Preparation of $\boldsymbol{V}$. articulatum Burm.f stock solution-} The $0.1 \mathrm{mM}$ DPPH solution was prepared with ethanol. 1 $\mathrm{ml}$ of solution was then added to $3 \mathrm{ml}$ of ethanol extract at varying concentrations $(50,100,150,200$ and 250 $\mu \mathrm{g} / \mathrm{ml}$ ). Only those extracts which are emulsifiable in ethanol are used here and their variable concentrations were prepared using the method of dilution. The mixture was then shaken vigorously and allowed to stand for 30 minutes at room temperature and thereafter absorbance was recorded at $517 \mathrm{~nm}$ by using a spectrophotometer

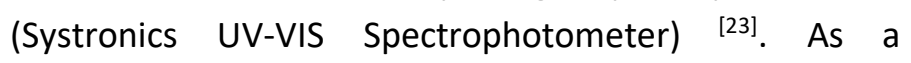
standard, Ascorbic acid was used for comparison by making the same dilutions as extracts of $V$. articulatum stocks $(50,100,150,200$, and $250 \mu \mathrm{g} / \mathrm{ml})$. A mixture of 1 $\mathrm{ml}$ of ethanol and $1 \mathrm{ml} \mathrm{DPPH}$ was used as a control and a formula was used to measure the percentage (\%) of inhibition/scavenging as- 


\section{A control - A sample

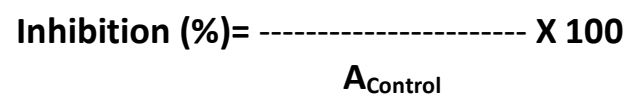

Where, $A_{\text {control }}=$ Control Absorbance, $\quad A_{\text {sample }}=$ Sample Absorbance

The graph was plotted with a concentration of $\mu \mathrm{g} / \mathrm{ml}$ on $\mathrm{X}$-axis and a percentage of inhibition on $\mathrm{Y}$-axis and the $\mathrm{IC}_{50}$ value of the sample, which was the sample concentration needed to inhibit $50 \%$ of the free radical DPPH, was determined using inhibition curve ${ }^{[24]}$.

\section{RESULTS}

Phytochemical profiling- The qualitative phytochemical assessment of $V$. articulatum was performed on six different extracts, i.e. petroleum ether, benzene, chloroform, acetone, ethanol and water, which revealed that phytoconstituents such as carbohydrates, cardiac glycosides, proteins, alkaloids, fats, saponins, coumarins, flavonoids, tannins, phenolics, steroids and quinine were prominently present. In all the extracts, however, anthraquinone glycoside was completely absent. The presence of carbohydrates, cardiac glycosides, proteins, alkaloids, saponins, flavonoids, fats, tannins and phenolics have been demonstrated in the ethanol extract of $V$. articulatum. Also, the presence of all compounds except steroids and quinone was shown by water extract. The existence of a minimum number of phytoconstituents was demonstrated by petroleum ether, benzene and chloroform extracts. The presence of alkaloids and proteins was only demonstrated by acetone, ethanol and water extract (Table 1).

Table 1: Qualitative phytochemical screening of V. articulatum Burm.f.

\begin{tabular}{|c|c|c|c|c|c|c|c|c|}
\hline \multirow{2}{*}{ S.No. } & \multirow{2}{*}{ Constituents } & \multirow{2}{*}{ Chemical Tests } & \multicolumn{6}{|c|}{ Extracts } \\
\hline & & & P.E. & B & $\mathrm{C}$ & A & $\mathbf{E}$ & $w$ \\
\hline \multirow[t]{4}{*}{1} & & Hager's Test & + & - & - & + & + & + \\
\hline & & Mayer's Test & - & - & - & + & + & + \\
\hline & Alkaloids & Wagner's Test & - & - & - & + & + & + \\
\hline & & Dragendroff's Test & - & - & + & + & + & + \\
\hline \multirow[t]{3}{*}{2} & Carbohydrates \& & Fehling's Test & - & - & + & - & - & - \\
\hline & Glycosides & Benedict's test & - & - & + & + & + & + \\
\hline & & Molisch's Test & - & + & + & + & + & + \\
\hline 3 & Steroids & Salkowski Test & + & + & - & + & + & - \\
\hline 4 & Saponin & Foam Test & - & + & + & - & + & + \\
\hline \multirow[t]{2}{*}{5} & Phenolics \& & $\mathrm{FeCl}_{3}$ Sol. Test & - & - & - & + & + & + \\
\hline & Tannin & Lead Acetate Test & - & - & - & + & + & + \\
\hline 6 & Fixed oil \& Fats & Spot Test & - & - & + & + & + & + \\
\hline \multirow[t]{2}{*}{7} & Proteins & Biuret Test & - & - & - & - & + & + \\
\hline & & Million's Test & - & - & - & + & + & + \\
\hline 8 & $\begin{array}{l}\text { Anthraquinone } \\
\text { glycosides }\end{array}$ & Borntrager's Test & - & - & - & - & - & - \\
\hline 9 & $\begin{array}{l}\text { Cardiac } \\
\text { glycosides }\end{array}$ & Keller-Killiani Test & + & + & + & - & + & + \\
\hline \multirow[t]{2}{*}{10} & Flavonoids & Shinoda Test & - & + & - & - & + & + \\
\hline & & Lead Acetate Test & - & - & + & + & + & + \\
\hline 11 & Quinone & & - & - & - & + & + & - \\
\hline 12 & Coumarins & & + & + & - & - & - & + \\
\hline
\end{tabular}


In-vitro Antioxidant activity- DPPH radical scavenging activity is primarily one of the methods for in vitro antioxidant screening of plant extracts ${ }^{[1]}$. Acetone and ethanolic extracts of $V$. articulatum were studied for antioxidant potential of different concentration of stock solutions viz. 50,100, 150, 200 and $250 \mu \mathrm{g} / \mathrm{ml}$. As a standard, ascorbic acid was used. The antioxidant characteristics depend on the value of $\mathrm{IC}_{50}$. Acetone and Ethanol extracts of $V$. articulatum showed increased in DPPH scavenging activity with a corresponding increase in its concentration (Table $2 \& 3$, Fig. 2 \& 3). Ethanol extract of this plant showed good antioxidant activity with an $\mathrm{IC}_{50}$ value of ascorbic acid. Fig. 2 and 3 shows the comparative data of DPPH radical scavenging activity of different extracts with standard ascorbic acid, respectively. The $\mathrm{IC}_{50}$ value was the concentration of the sample required to inhibit $50 \%$ of the free radicals present in the system. Conversely, the $I_{50}$ value was connected to the crude extract's antioxidant activity. In this result, $I C_{50}$ value was lower and the antioxidant activity was the more. Based on the result obtained, ethanolic extract of this plant showed good antioxidant activity (i.e. $\mathrm{IC}_{50}=8.9$ ) than that of the acetone extract (i.e. $I C_{50}=9.4$ ) as compared to standard ascorbic acid (i.e. $\left.\mathrm{IC}_{50}=5.4\right)$ as shown in Table 4 and Fig. 4, 5 and 6.

Table 2: Antioxidant activity of $V$. articulatum Burm.f. acetone extract

\begin{tabular}{cccc}
\hline \multirow{2}{*}{ S. No. } & Concentration $(\mu \mathrm{g} / \mathrm{ml})$ & Acetone extract & Ascorbic acid \\
\cline { 3 - 4 } & 50 & $55.40 \pm 0.46$ & $60.32 \pm 0.05$ \\
\hline 1 & 100 & $62.78 \pm 0.60$ & $68.33 \pm 0.16$ \\
3 & 150 & $65.44 \pm 0.51$ & $80.21 \pm 0.04$ \\
4 & 200 & $75.54 \pm 0.13$ & $96.90 \pm 0.12$ \\
5 & 250 & $81.13 \pm 0.31$ & $97.25 \pm 0.1$
\end{tabular}

Values represent mean \pm SD $(n=3)$

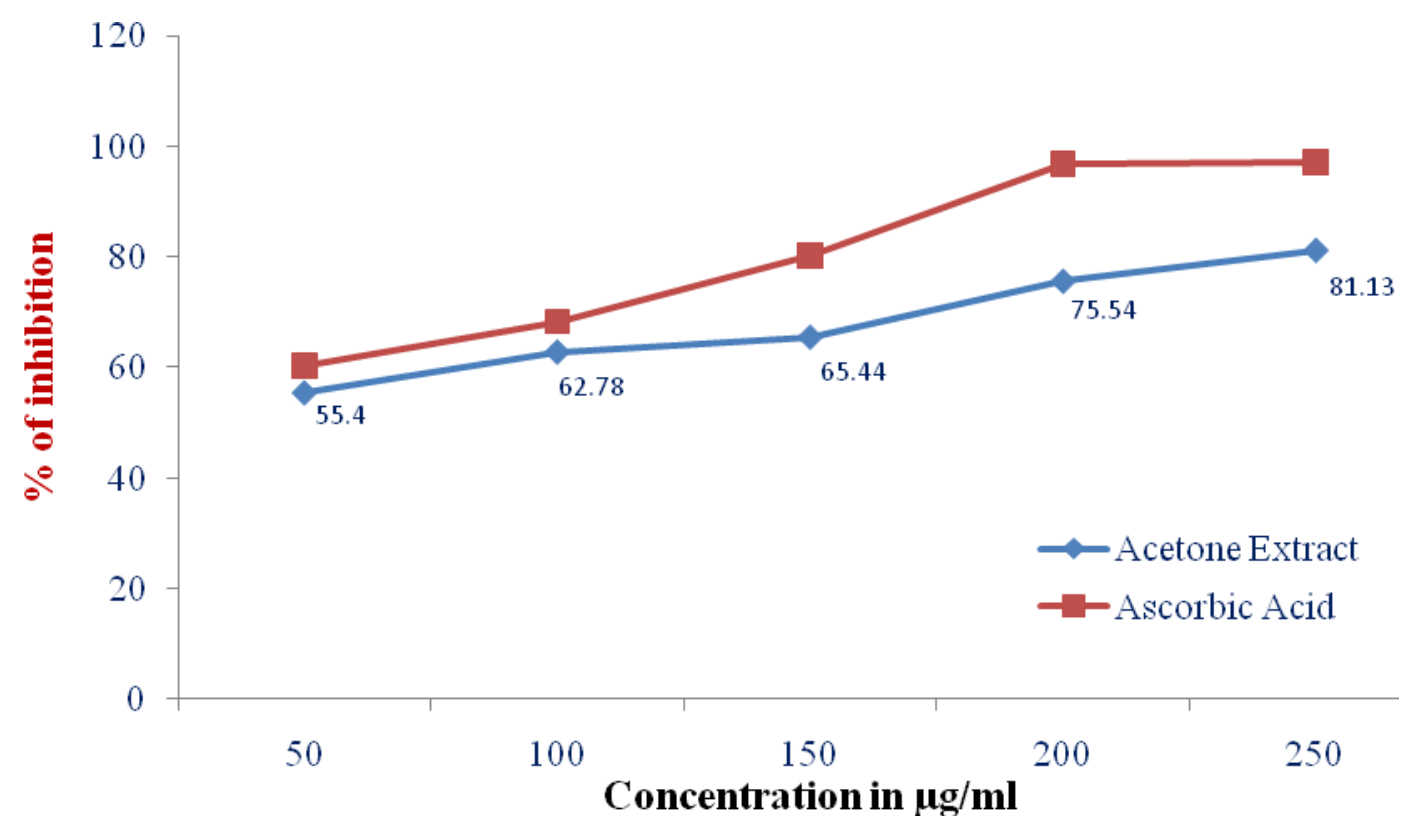

Fig. 2: Antioxidant activity of $V$. articulatum Burm. facetone extract 
Table 3: Antioxidant activity of $V$. articulatum Burm.f. ethanol extract

S. No. Concentration $(\mu \mathrm{g} / \mathrm{ml})$

Inhibition (\%)

\begin{tabular}{cccc}
\cline { 3 - 3 } & & Ethanol extract & Ascorbic acid \\
\hline 1 & 50 & $58.38 \pm 0.47$ & $60.32 \pm 0.05$ \\
2 & 100 & $60.40 \pm 0.40$ & $68.33 \pm 0.16$ \\
3 & 150 & $71.31 \pm 0.30$ & $80.21 \pm 0.04$ \\
4 & 200 & $78.47 \pm 0.33$ & $96.90 \pm 0.12$ \\
5 & 250 & $86.62 \pm 0.34$ & $97.25 \pm 0.1$
\end{tabular}

Values represent mean \pm SD $(n=3)$

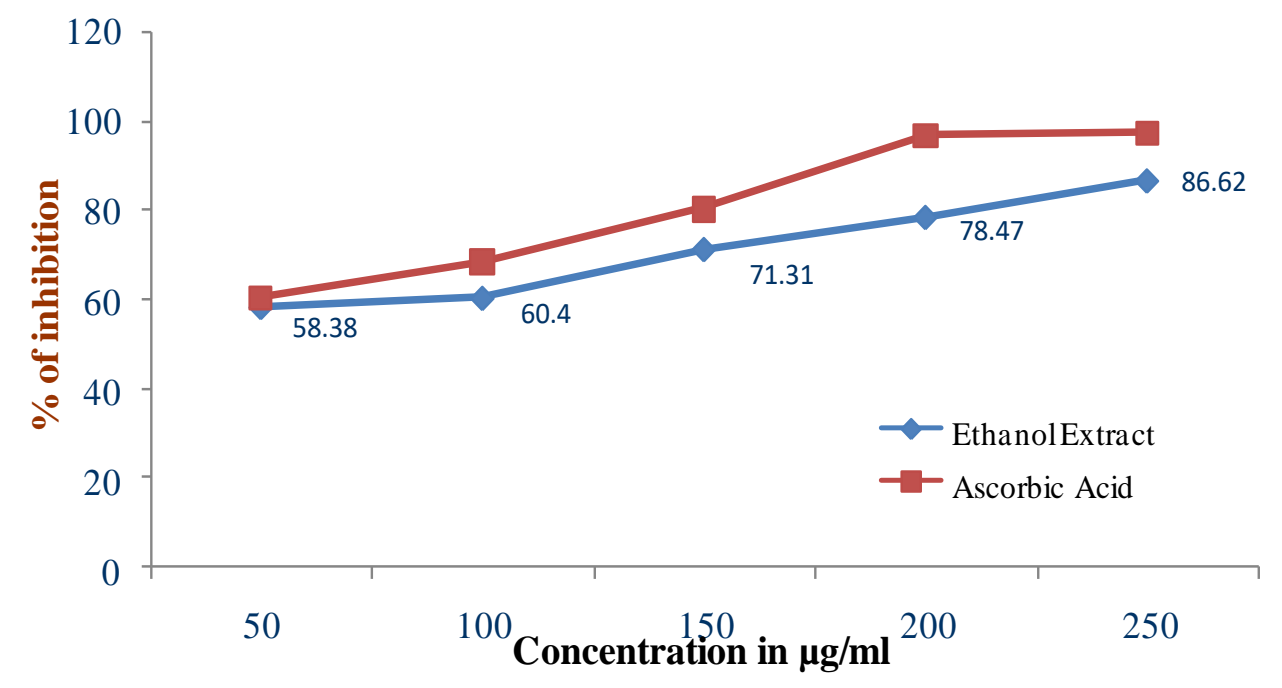

Fig. 3: Antioxidant activity of $V$. articulatum Burm.f ethanol extract

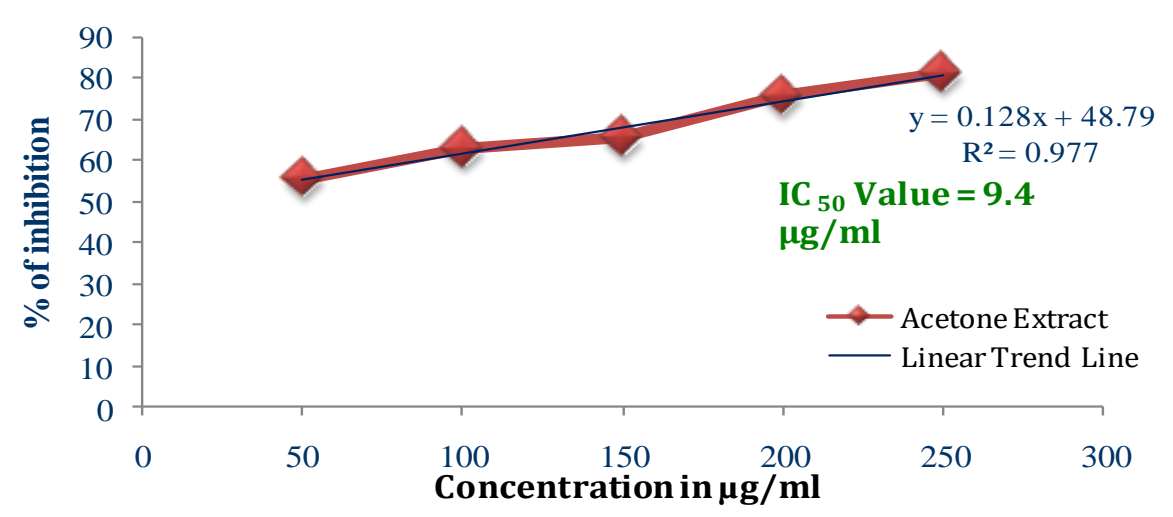

Fig. 4: $I C_{50}$ calculation of $V$. articulatum Burm. $f$ in acetone extract 


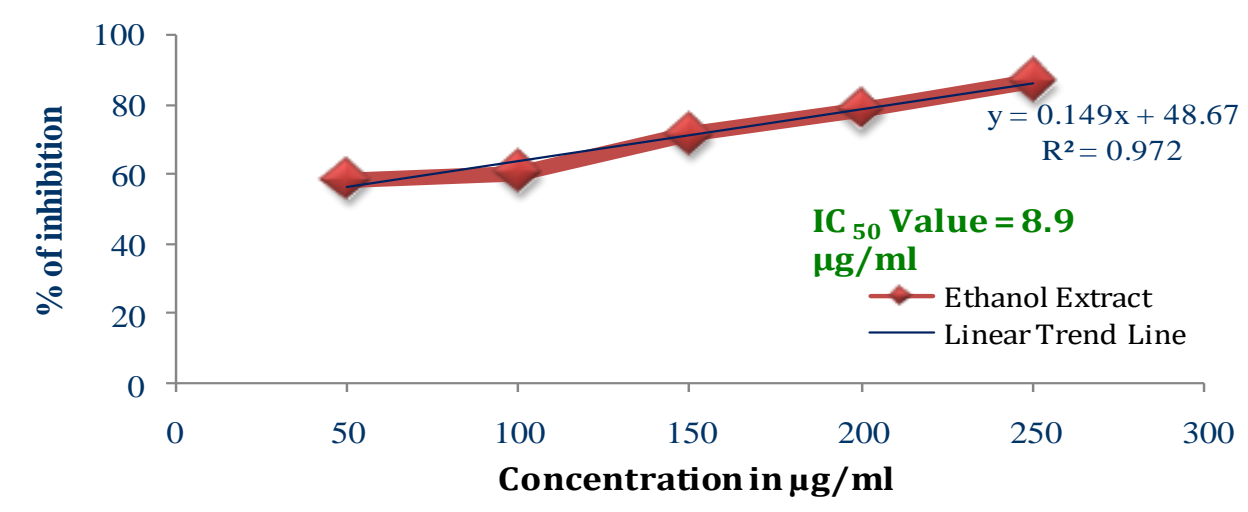

Fig. 5: IC $C_{50}$ calculation of $V$. articulatum Burm.f. in ethanol extract

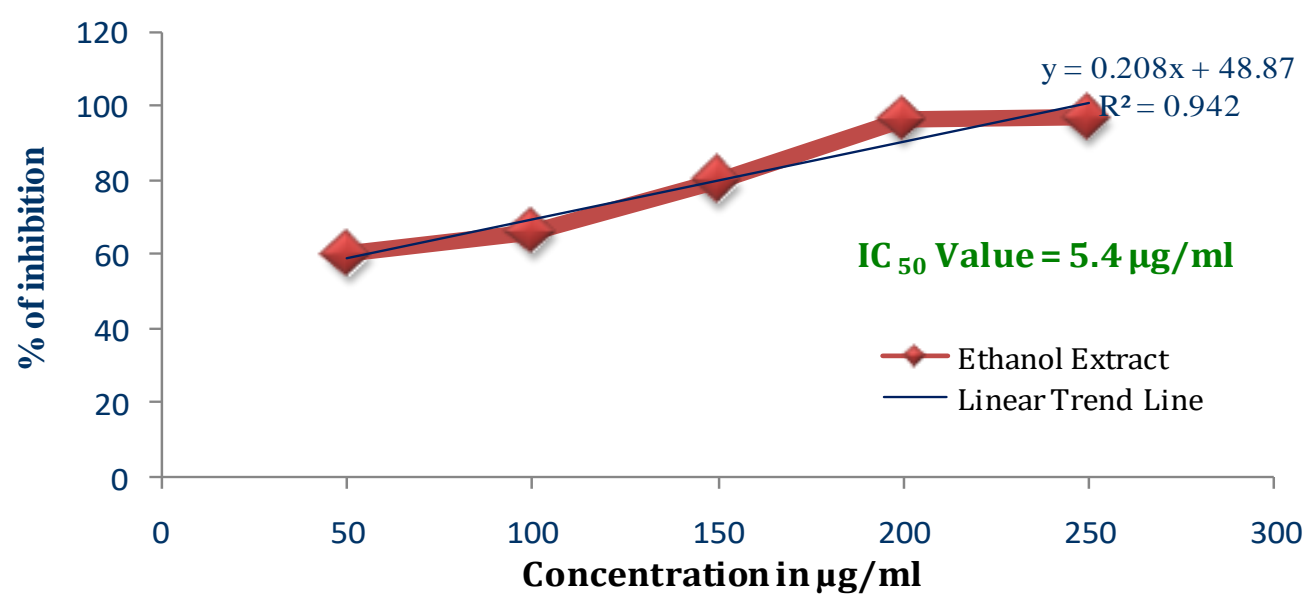

Fig. 6: IC $\mathrm{C}_{50}$ calculation of Standard (Ascorbic Acid)

Table 4: $I C_{50}$ values of $V$. articulatum Burm.f of different extracts and Ascorbic acid

\begin{tabular}{ccc}
\hline S. No. & Extracts & IC $_{50}$ values $(\mu \mathrm{g} / \mathrm{ml})$ \\
\hline 1 & Acetone extract of $V$. articulatum Burm. & 9.4 \\
2 & Ethanolic extract of $V$. articulatum Burm.f & 8.9 \\
3 & Ascorbic acid & 5.4 \\
\hline
\end{tabular}

Using the fitted line, $I C_{50}$ values are calculated, i.e. $Y=a * X+b, I C_{50}=(50-b) / a$

\section{DISCUSSION}

Medicinal plants have played a crucial role in the prevention and the treatment of different ailments since ancient times ${ }^{[25]}$. In the current research work, I have decided to scientifically explore the uses of $V$. articulatum Burm. f., like to investigate their phytoconstituents and antioxidant activity. In the present work, the phytochemical profile of $V$. articulatum reveals the prominent presence of carbohydrates, cardiac glycosides, proteins, alkaloids, fats, saponin, coumarins, flavonoids, tannins, phenolics, steroids and quinone. The earlier phytochemical reports on $V$. articulatum are still scarce; some are given by Geetha et al. ${ }^{[26]}$, Najafi et al. ${ }^{[27]}$ and Vadnere et al. ${ }^{[28]}$, which also showed the presence of similar phytoconstituents as observed in the present study. Some 
biological activities of these phytoconstituents of $V$. articulatum were also reported ${ }^{[21,26]}$.

The plant has a large number of phyto-constituents such as flavonoid and phenols are reported to exhibit good antioxidant property ${ }^{[27]}$. In the present work, DPPH radical scavenging assay of $V$. articulatum was studied for antioxidant potential. Since it is a water-soluble free radical scavenger, ascorbic acid has been used as the standard. In addition, in conjuction with the compounds capable of donating reducing equivalents, it regenerates vitamin $\mathrm{E}$ in the cell membrane. By donating an electron to the lipid radical to end the lipid peroxidation chain response, ascorbic acid switches to the ascorbate radical ${ }^{[29]}$. DPPH is a stable free radical at room temperature and accepts an electron or hydrogen radical to become a stable diamagnetic molecule. The reduction capability of DPPH radicals was determined by decreasing absorbance at $517 \mathrm{~nm}$, which was induced by antioxidants ${ }^{[30]}$. Lesser, the $I C_{50}$ value more is the antioxidant activity ${ }^{[24]}$.

The findings obtained showed that this plant's ethanolic extract has high antioxidant activity (i.e. $\mathrm{IC}_{50}=8.9$ ) compared to that of the acetone extract (i.e. $I C_{50}=9.4$ ) compared to regular ascorbic acid (i.e. $I C_{50}=5.4$ ). Through current methodology, there is no work performed on the antioxidant activity of $V$. articulatum acetone and ethanolic extract. Kannoth et al. ${ }^{[21]}$ have reported various assay methods for the single $V$. articulatum methanolic extract and have obtained significant results. So, it is possible to consider the $V$. articulatum plant as an excellent antioxidant.

\section{CONCLUSIONS}

The current research work shows that both $V$. articulatum Burm. f. acetone and ethanolic extract, it is a strong source of antioxidant property containing various phytochemicals. The presence of carbohydrates, cardiac glycosides, proteins, alkaloids, fats, saponin, coumarins, flavonoids, tannins, phenolics, steroids and quinone present in these extracts may be responsible for antioxidant activity. From this report, it was concluded that the plant $V$. articulatum Burm.f. has a remarkable antioxidant effect, which may be useful for its novel applications because of its medicinal values.

\section{ACKNOWLEDGMENTS}

The authors express sincere thanks to Principal, L. R. Bharti Arts, Commerce and S. S. R. Bharti Science
College, Arni, Dist-Yavatmal for their encouragement toward research.

\section{CONTRIBUTION OF AUTHORS}

Research concept- Dr. M. R. Kakpure

Research design- Dr. M. R. Kakpure

Supervision- Dr. M. R. Kakpure

Materials- Dr. M. R. Kakpure

Data collection- Dr. M.R. Kakpure

Data analysis and Interpretation- Dr. M.R. Kakpure

Literature search- Dr. M.R. Kakpure

Writing article- Dr. M.R. Kakpure

Critical review- Dr. M. R. Kakpure

Article editing- Dr. M. R. Kakpure

Final approval- Dr. M. R. Kakpure

\section{REFERENCES}

[1] Faraone I, Rai DK, Lucia C, Eloy F, Choudhary A, et al. Antioxidant activity and phytochemical characterization of Senecio clivicolus Wedd. Mol., 2018; 23(10): 2497-503.

[2] Tripathi R, Mohan H, Kamat JP. Modulation of oxidative damage by natural products. Food Chem., 2007; 100: 81-90.

[3] Bagul MS, Ravishankar MN, Padh H, Rajini M. Phytochemical evaluation and free radical scavenging activity of rhizome of Bergeniaciliate (Haw) Sternb: Forma ligulata Yeo J Nat Remed., 2003; 3: 83-90.

[4] Ozsoy N, Yanardag R, Akev N. Antioxidant activity of Smilax excelsa L. Leaf Extracts. Food Chem., 2008; 110: 571-83.

[5] Chiavaroli V, Giannini C, De Marco S, Chiarelli F, Mohan $A$, et al. Unbalanced oxidant-antioxidant status and its effects in pediatric diseases. Redox Rep., 2011; 16: 101-07.

[6] Kanwar JR, Kanwar RK, Burrow H, Baratchi S. Recent advances on the roles of NO in cancer and chronic inflammatory disorders. Curr. Med. Chem., 2009; 16: 2373-94.

[7] Ikram I, Samar S, Khan I, Izhar A. In vitro antioxidant activities of four medicinal plants on the basis of DPPH free radical scavenging. Pak J Pharm Sci., 2013; 26(5): 949-52.

[8] Wu YY, Li W, Xu Y, Jin EH, Tu YY, et al. Evaluation of the antioxidant effects of four main theaflavin derivatives through chemiluminescence and DNA 
damage analyses. J. Zhejiang Univ Sci., 2011; 12: 744-51.

[9] Ravishankar MN, Srivastava N, Padh H, Rajani M. Evaluation of Antioxidant Properties of root bark of Hemidesmus indicus. Phytomed., 2002; 9: 15360.

[10]Sathisha A, Lingaraju HB, Sham Prasad K. Evolution of antioxidant activity of medicinal plant extract produced for commercial purpose. J Chem., 2011; 8(2): 882-86.

[11]Naik VN. Flora of Marathwada. Vol. I \& II, Aurangabad; Amrut Prakashan, 1998.

[12]Almeida MR. Flora of Maharashtra.Vol. III B, Mumbai; Orient Press, 2001.

[13]Singh NP, Lakshminarasimhan P, Kartikeyan S, Prasanna PV. Flora of Maharashtra State.Vol. II, Botanical Survey of India, Calcutta, 2001.

[14]Wallis TE. Text Book of Pharmacognosy. $5^{\text {th }}$ Edn., New Delhi; CBS Publishers \& Distributors, 1990.

[15]Harborne JB. Phytochemical Methods. $3^{\text {rd }}$ Edn., London; Chapman \& Hall Publication, 1998.

[16]Kokate, CK, Purohit AP, Gokhale SB. Pharmacognosy. Pune; Nirali Prakashan, 2005.

[17]Sadashivan S, Manickam A. Biochemical Methods. $2^{\text {nd }}$ Edn., New Delhi; New Age International (P) Ltd., Publisher, 2005.

[18]Rajurkar NS, Harde SM. Estimation of Phytochemical Contents and Antioxidant Activity of Some Selected Traditional Indian Medicinal Plants. Ind J Pharma Sci., 2011; 73(2): 146-51.

[19]Anandjiwala S, Bagul MS, Parabia M, Rajani M. Evaluation of free radical scavenging activity of an Ayurvedic formulation, panchvalkala. Ind J Pharma Sci., 2008; 70: 31-50.

[20]Marinova G, Butchvarov V. Evaluation method for the determination of free radical scavenging activity by DPPH. Bulg J Agri Sci., 2011; 17(1): 11-24.
[21]Kannoth MG, Venkatesh $B$, Vedigounder $M$. Antioxidant potential of Viscum articulatum Burm. Chronicles of Young Scientists, 2013; 4(1): 32-35.

[22] Tailor CS, Goyal A. Antioxidant Activity by DPPH Radical Scavenging Method of Ageratum conyzoides Linn. Leaves. Am J Ethnomed., 2014; 1(4): 244-49.

[23]Jamuna S, Paulsamy SP, Kasthika K. Screening of in vitro antioxidant activity of metabolic extract of Hypochaeris radicata L.(Asteraceae). J Appl Pharma Sci., 2012; 2(7): 149-54.

[24]Nariya PB, Nayan RB, Shukla VJ, Rabinarayan A, Nariya MB. In vitro evaluation of antioxidant activity of Cordia dichotoma (Forst f.) bark. Ayu J., 2013; 34(1): 124-28.

[25]Assefa B, Glatzel G, Buchmann C. Ethnomedicinal uses of Hagenia abyssinica (Bruce) J.F.Gmel. among rural community of Ethiopia. J Ethnobio Ethnomed., 2010; 6(1): 20.

[26]Geetha KM, Bhaskara PVVS, Murugan V. Antiepileptic activity of aerial parts of Viscum articulatum (Viscaceae) in rats. J Pharma Res., 2010; 3(12): 2886-87.

[27]Najafi S, Sadeghi NB, Deokule SS, Estakhr J. Phytochemical screening of Bidaria khandalense Sant.; Loranthus capitellatus Wall., Viscum articulatum Burm.f. and Vitex negundo L. Res J Pharma Biol Chem Sci., 2010; 1(3): 388-93.

[28]Vadnere GP, Singhai AK, Pathan AR. Pharmacognostical and phytochemical studies of Viscum articulatum Burm. f. Planta Activa., 2012; 3: 16-22.

[29]Nimse Sb, Pal DK. Free radicals, natural oxidants and their reaction mechanisms, RSC Adv., 2015; 5: 27986-8006. doi: 10.1039/C4RA13315C.

[30] Kunchndy E. Oxygen radical scavenging activity of Curcumin. Int. J. Pharmacol., 1990; 58: 237-40. 